\title{
PENGARUH MODEL PEMBELAJARAN INQUIRY TRAINING TERHADAP HASIL BELAJAR SISWA PADA MATERI POKOK KALOR DI KELAS VII SEMESTER II SMP SWASTA AN-NIZAM MEDAN
}

\author{
Khairunnisa Padang dan Ratna Tanjung \\ best.khairun@gmail.com \\ Jurusan Fisika FMIPA Universitas Negeri Medan \\ Jalan Willem Iskandar Pasar V Medan, 20221
}

\begin{abstract}
This study aims to determine: 1) physics student learning outcomes 2) students during the learning activity 3) differences due to the effect of the application of inquiry learning model of training on student learning outcomes. This research is a quasi experimental research design with two group pretest-posttest design. The study population was all students of class VII Semester II Private SMP An-Nizam field consisting of 3 classes. Sampling was done by cluster random sampling by taking two classes, namely class VII-A class of experimental class and control class VII-C. The instrument used in this study is twofold: 1) achievement test 2) the observation sheet. Observation sheet consists of assessment activity, affective and skills. Hypothesis testing using t-test. The results were obtained an average value of the experimental class pretest 34.65 with $\mathrm{SD}=13.1$ and the mean posttest score 76.48 with $\mathrm{SD}=8.6$. In the control group pretest value rearata 31.74 with $\mathrm{SD}=11.8$ and the mean posttest score 68.34 with SD $=8.6$. Learning activities in the classroom experiment is $70.94 \%$ and $60.87 \%$ in the control class, so the class concluded the experiment had increased activity higher than in the control class. Increased affective experimental class students $62.20 \%$ and $57.60 \%$ control class, so that concluded increased affective experimental class higher than the control class. The development of an experimental class students' skills increase, $69.05 \%$ at the first meeting, the second meeting of $70.94 \%, 72.84 \%$ III meeting. So the average value during the learning skills of the students $70.94 \%$ (active). Data obtained from testing the hypothesis that the post-test $\mathrm{t}=36.50$ at significance level $\mathrm{a}=0.05$ and price table $=1.669$. So tcount $>\mathrm{t}$ table $(3.960>1.668)$ then $\mathrm{Ho}$ is rejected and Ha accepted. It can be concluded that there is no influence of the application of inquiry learning model of training in the heat of the material in class VII Semester II Private SMP An-Nizam TP 2013/2014.
\end{abstract}

Keyword : Inquiry Training, Hasil Belajar, Kalor

\section{PENDAHULUAN}

Fisika merupakan bagian utama dari mata pelajaran Ilmu Pengetahuan Alam (IPA) yang pada dasarnya menarik untuk dipelajari karena didalamnya dapat dipelajari gejala-gejala atau fenomena yang terjadi di jagad raya. Namun 
kenyataan menunjukan bahwa masih banyak timbul sorotan dari berbagai pihak tentang prestasi anak didik, terutama dalam bidang IPA khususnya fisika dimana hasil belajar yang dicapai siswa dalam mata pelajaran fisika masih sangat rendah.

Berdasarkan hasil wawancara dengan salah satu guru fisika yang menagajar di SMP Swasta AnNizam Medan mengatakan bahwa hasil belajar fisika siswa masih rendah dengan nilai rata- rata 65 di bawah Kriteria Ketuntasan Minimal (KKM). Siswa yang memenuhi KKM hanya sekitar $20 \%$, sedangkan KKM di sekolah tersebut adalah 75 . Rendahnya nilai ratarata siswa disebabkan guru tidak menggunakan model pembelajaran yang bervariasi. Hal ini dapat dilihat dari observasi yang dilakukan peneliti di SMP Swasta An-Nizam Medan dengan menyebarkan angket kepada 35 siswa kelas VII diperoleh data bahwa 21 orang mengatakan fisika itu sulit dan kurang menarik, karena guru selalu menyajikan materi fisika dalam bentuk rumusrumus dan perhitungan. Delapan orang mengatakan fisika itu biasa saja. Sedangkan enam orang mengatakan bahwa fisika itu mudah dan menyenangkan.

Rendahnya hasil belajar, dikarena guru hanya cenderung menjelaskan materi dan mengerjakan soal. Proses pembelajaran tersebut dapat menimbulkan kebosanan sehingga peran siswa dalam proses pembelajaran kurang aktif dan siswa lebih banyak mendengarkan. Siswa kurang aktif pada saat pembelajaran fisika berlangsung ini ditandai dengan sebagian siswa cepat putus asa jika menghadapi soal yang sulit sehingga hanya menunggu jawaban dari temannya saja dan siswa tidak sungguhsungguh mengikuti pelajaran di dalam kelas, masih banyak siswa yang takut untuk belajar fisika dan siswa masih sering menghapal bukan mengalami. Siswa juga masih takut untuk bertanya pada guru jika ada materi yang tidak dipahami karena terbiasa pasif menerima apa yang diberikan guru dan siswa merasa mendapatkan tekanan dari diri sendiri ketika pertanyaannya sering dicemooh, disepelekan oleh temannya serta siswa takut dengan sikap guru yang otoriter. Selanjutnya siswa tidak mampu melihat manfaat atau keterkaitan diantara materi yang dipelajari dengan dunia nyata yang mereka alami.

Menyikapi rendahnya hasil belajar fisika tersebut, perlu adanya upaya yang dilakukan oleh guru, salah satu alternatif solusi yang diambil adalah dengan menerapkan model pembelajaran inquiry training. Menurut Joyce., at al (2009: 201) menyatakan bahwa model pembelajaran inquiry training dirancang untuk membawa siswa secara langsung ke dalam proses ilmiah melalui latihanlatihan yang dapat memadatkan proses ilmiah tersebut ke dalam periode waktu yang singkat. Tujuannya adalah membantu siswa mengembangkan displin dan keterampilan intelektual yang diperlukan untuk mengajukan pertanyaan dan menemukan jawabannya berdasarkan rasa ingin tahunya.

Melalui model pembelajaran inquiry training ini mengharapkan siswa untuk berperan aktif 
mengajukan pertanyaan mengapa sesuatu terjadi kemudian mencari dan mengumpulkan serta memproses data secara logis untuk selanjutnya mengembangkan strategi intelektual yang dapat digunakan untuk dapat menemukan jawaban atas pertanyaan mengapa sesuatu terjadi. Inquiry training dimulai dengan menyajikan masalah yang memerlukan jawaban siswa. Siswasiswa yang menghadapi situasi tersebut akan termotivasi menemukan jawaban masalah tersebut. Guru dapat menggunakan kesempatan ini untuk menciptakan proses belajar mengajar yang menarik dan menyenangkan dengan cara bersikap ramah dan bersahabat kepada siswa sehingga siswa tidak memiliki rasa takut untuk berbicara. Melalui proses pembelajaran ini, siswa difasilitasi untuk berfikir dan mengajukan pertanyaan. Dalam pembelajaran inquiry training tugas guru adalah memfasilitasi siswa untuk meneliti, bukan melakukan penelitian untuk siswa. Jika guru ditanyai pertanyaan yang tidak bisa dijawab dengan kata "ya" atau "tidak", maka guru harus meminta siswa untuk menyusun kembali pertanyaannya agar siswa bisa melanjutkan upayanya untuk mengumpulkan data dan menghubungkannya pada permasa lahan, dengan demikian akan terjadi komunikasi yang baik antara guru dan siswa dalam proses belajar mengajar.

Adapun fasae-fase dalam Model pembelajaran inquiry traning yairu: 1) Menghadapkan Pada Masalah, 2) Pengumpulan DataVerifikasi, 3) Pengumpulan DataEksperimentasi, 4) Mengolah, memformulasikan suatu penjelasan, dan 5) Analisis proses penelitian

Penelitian sebelumnya oleh Harahap (2012) diperoleh nilai rata-rata pretes 46,29 dan setelah diberikan perlakuan yaitu model pembelajaran inquiry traning maka hasil belajar siswa meningkat dengan nilai rata-rata 75,39. Adapun kelemahan dalam penelitian ini adalah peneliti kurang memperhatikan kemampuan awal siswa dan kurang mempersipakan permasalahan yang menggugah rasa ingin tahu siswa sehingga siswa kurang termotivasi untuk menemukan jawaban dari permasalahan.

Sebagai

pembenahan pemaparan masalah di atas, salah satu cara yang dapat dilakukan untuk memperbaiki proses pembelajaran adalah dengan menerapkan model pembelajaran inquiry training.

\section{METODE PENELITIAN}

Penelitian ini dilaksanakan di SMP Swasta An-Nizam Medan dengan populasi seluruh siswa kelas VII SMP Swasta An-Nizam Medan yang terdiri dari tiga kelas dengan jumlah 105 siswa. Teknik pengambilan sampel dilakukan dengan cara teknik sampel kelas acak (cluster random sampling). Sampel kelas diambil dari populasi sebanyak dua kelas yaitu kelas VIIA sebagai kelas eksperimen dan kelas VII-B sebagai kelas kontrol. Jenis penelitian ini adalah kuasi eksperimen ini dengan desain two group pretest-postest design.

Alat pengumpul data dalam penelitian ini adalah tes berbentuk esay sebanyak 12 soal dan lembar observasi untuk mengetahui 
aktivitas, sikap dan keterampilan siswa.

\section{HASIL PENELITIAN DAN PEMBAHASAN \\ Hasil Penelitian}

Hasil pretes kelas eksperimen dengan nilai rata-rata 34,65 dan kelas kontrol adalah 31,74. Setelah memperoleh data hasil pretes siswa dari kelas eksperimen dan kelas kontrol, maka dilakukan pengujian analisis data dengan menggunakan uji kesamaan rata-rata pretes dimana syaratnya data harus berdistribusi normal dan homogen. Hasil Hasil uji normalitas, homogenitas dan kesamaan ratarata pretes ditunjukkan pada Tabel 1.

Tabel 1. Hasil Uji Normalitas, Homogenitas dan Kesamaan Ratarata Pretes

\begin{tabular}{|c|c|c|c|c|c|c|c|}
\hline Kelas & $\begin{array}{r}\text { Rata }^{-} \\
\text {rata }\end{array}$ & Lhit & $\mathbf{L}_{\text {tab }}$ & $F_{\text {hit }}$ & $F_{\text {tab }}$ & $t_{\text {hit }}$ & $\mathrm{t}_{\mathrm{tal}}$ \\
\hline $\begin{array}{l}\text { Eks } \\
\text { peri } \\
\text { men }\end{array}$ & $\begin{array}{l}34, \\
65\end{array}$ & $\begin{array}{l}0,1 \\
19\end{array}$ & \multirow{2}{*}{$\begin{array}{l}0,1 \\
4\end{array}$} & \multirow{2}{*}{$\begin{array}{l}1,2 \\
7\end{array}$} & \multirow{2}{*}{$\begin{array}{l}1,7 \\
6\end{array}$} & \multirow{2}{*}{$\begin{array}{l}0,9 \\
7\end{array}$} & \multirow{2}{*}{$\begin{array}{l}1,9 \\
9\end{array}$} \\
\hline $\begin{array}{l}\text { Kon } \\
\text { trol }\end{array}$ & $\begin{array}{l}31, \\
74\end{array}$ & $\begin{array}{l}0,0 \\
72\end{array}$ & & & & & \\
\hline \multicolumn{2}{|c|}{ Kesimpulan } & \multicolumn{2}{|c|}{ Normal } & \multicolumn{2}{|c|}{ Homogen } & \multicolumn{2}{|c|}{$\begin{array}{c}\text { Kemampu } \\
\text { an awal } \\
\text { siswa } \\
\text { sama }\end{array}$} \\
\hline
\end{tabular}

Berdasarkan Tabel 1 data pretes kedua kelas normal, homogen dan tidak ada perbedaan secara signifikan, maka pada kedua kelas sampel diberikan perlakuan yang berbeda, pada kelas eksperimen diberikan perlakuan dengan menerapkan model pembelajaran inquiry traning sedangkan pada kelas kontrol diberikan perlakuan dengan menerapkan pembelajaran konvensional.
Penilaian aktivitas belajar siswa selama pembelajaran dilaku kan dengan cara observasi yang dilakukan dengan tiga observer yaitu 1 orang guru mata pelajaran fisika dan 2 rekan peneliti. Observasi dilakukan selama kegiatan belajar mengajar yang terdiri dari tiga kali pertemuan. Dalam penelitian ini, jenis aktivitas yang diamati adalah : (1) listening activities, (2) oral activities, (3) motor activities, (4) mental activities, (5) writing activities. Hasil observasi aktivitas para observer untuk kelas eksperimen menunjukkan rata - rata skor aktivitas siswa dari pertemuan 1 sampai 3 mencapai 70,66 (kategori aktif).

Penilaian keterampilan tampak dalam bentuk keterampilan (skill) dan kemampuan bertindak individu. Dalam penelitian ini yang menjadi aspek-aspek penilaian keterampilan adalah melakukan percobaan dan mengamati percobaan. Hasil perkembangan keterampilan siswa kelas eksperimen dari pertemuan I samapi III mengalami peningkatan dengan nilai rata-rata 70,94\%. Berikut perkembangan keterampilan siswa kelas eksperimen ditunjukan pada Tabel 2.

Tabel 2. Penilaian Keterampilan Siswa pada Pertemuan I, II dan III

\begin{tabular}{|c|c|c|c|}
\hline No & $\begin{array}{c}\text { Pertemu } \\
\text { an }\end{array}$ & $\begin{array}{c}\text { Rata-rata } \\
\text { Keterampilan } \\
\text { Siswa }\end{array}$ & Kriteria \\
\hline 1 & I & 69,05 & Baik \\
\hline 2 & II & 70,94 & Baik \\
\hline 3 & III & 72,84 & Baik \\
\hline
\end{tabular}


Penilaian sikap harus menjadi bagian integral dari hasi belajar dan harus tampak dalam proses belajar yang dicapai oleh siswa yang dinilai hasil-hasilnya. Dalam penelitian ini yang menjadi aspekaspek dalam penilaian sikap adalah karakter (logis, kritis, teliti, jujur, berperilaku santun, dan memiliki rasa ingin tahu) dan keterampilan sosial (bekerjasama, menyampaikan pendapat dan menanggapi pendapat orang lain). Hasil penilaian sikap siswa kelas eksperimen dan kelas kontrol dapat ditunjukkan pada Tabel 3.

Tabel 3. Penilaian Sikap Siswa pada Pertemuan I, II dan III

\begin{tabular}{|c|c|c|c|c|}
\hline $\begin{array}{c}\mathbf{N} \\
\mathbf{0}\end{array}$ & Kelas & $\begin{array}{c}\text { \% } \\
\text { Pert I }\end{array}$ & $\begin{array}{c}\text { \% Pert } \\
\text { II }\end{array}$ & $\begin{array}{c}\text { \% Pert } \\
\text { III }\end{array}$ \\
\hline 1 & $\begin{array}{c}\text { Kelas } \\
\text { Eksperimen }\end{array}$ & 54 & 62,11 & 70,05 \\
\hline 2 & Kelas Kontrol & 52,97 & 54,62 & 65,22 \\
\hline
\end{tabular}

Setelah diberikan perlakuan yang berbeda, kedua kelas diberikan postes untuk melihat adanya perbedaan akibat penerapan model pembelajaran yang berbeda. Hasil rata-rata postes kelas eksperimen memperoleh nilai rata- rata 76,48 , sedangkan nilai rata-rata postes kelas kontrol adalah 68,34. Hasil uji normalitas, homogenitas dan hipotesis siswa ditunjukkan Tabel 4.
Tabel 4. Hasil Uji Normalitas, Homogenitas dan Hipotesis Siswa

\begin{tabular}{|c|c|c|c|c|c|c|c|}
\hline $\begin{array}{l}\text { Ke } \\
\text { las }\end{array}$ & $\begin{array}{l}\text { ata- }^{-} \\
\text {rata }\end{array}$ & $\begin{array}{c}\mathrm{L}_{\mathrm{hi}} \\
\text { tun } \\
\mathrm{g}\end{array}$ & $\begin{array}{c}\mathrm{L}_{\mathrm{ta}} \\
\text { bel }\end{array}$ & $\begin{array}{c}F_{h i} \\
t\end{array}$ & $\begin{array}{c}\mathrm{F}_{\mathrm{ta}} \\
\mathrm{b}\end{array}$ & $t_{\text {hit }}$ & $\mathrm{t}_{\text {tab }}$ \\
\hline $\begin{array}{l}\text { Eks } \\
\text { peri } \\
\text { men }\end{array}$ & $\begin{array}{c}76,4 \\
8\end{array}$ & $\begin{array}{l}0,0 \\
66\end{array}$ & \multirow{2}{*}{$\begin{array}{l}0,1 \\
4\end{array}$} & \multirow{2}{*}{$\begin{array}{c}1,0 \\
0\end{array}$} & \multirow{2}{*}{$\begin{array}{c}1,7 \\
6\end{array}$} & \multirow[t]{2}{*}{3,9} & \multirow[t]{2}{*}{1,6} \\
\hline $\begin{array}{l}\text { Kon } \\
\text { trol }\end{array}$ & $\begin{array}{c}68,3 \\
4\end{array}$ & $\begin{array}{l}0,0 \\
81\end{array}$ & & & & & \\
\hline \multicolumn{2}{|c|}{ Kesimpulan } & \multicolumn{2}{|c|}{ Normal } & \multicolumn{2}{|c|}{$\begin{array}{c}\text { Homoge } \\
n\end{array}$} & \multicolumn{2}{|c|}{$\begin{array}{c}\text { Ada } \\
\text { perbeda } \\
\text { an yang } \\
\text { signifika } \\
\mathrm{n}\end{array}$} \\
\hline
\end{tabular}

Berdasarkan Tabel 4 diperoleh bahwa data postes, kedua kelas normal, homogen dengan nilai $t_{\text {hitung }}>t_{\text {tabel }}$ yaitu $3,97>1,6$, sehingga dapat disimpulkan bahwa ada pengaruh model inquiry traning yang signifikan terhadap hasil belajar siswa pada materi kalor kelas VII SMP Swasta An-Nizam Medan.

\section{Pembahasan}

Hasil penelitian menunjukkan bahwa hasil belajar fisika dengan menggunakan model pembelajaran inquiry training lebih baik dari pada pembelajaran konvensional. Hal ini dibuktikan dengan perolehan nilai rata-rata pretes siswa kelas eksperimen sebesar 34,65 dan nilai rata-rata postes sebesar 76,48, sedangkan rata-rata pretes siswa kelas kontrol sebesar 31,74 dan nilai rata-rata postes sebesar 68,34.

Awal dari tahap ini peneliti memberikan penjelasan kepada siswa mengenai tujuan yang harus dicapai baik tujuan yang berhubungan dengan penguasaan materi pelajaran yang harus 
dicapai, maupun tujuan yang berhubungan dengan proses pembela jaran serta memotivasi siswa agar lebih aktif dalam belajar. Akan sulit bagi siswa untuk melaksanakan suatu tugas dengan baik apabila belum mengetahui jelas tentang apa dan mengapa melakukan suatu kegiatan atau apabila kriteria keberhasilan belum diberitahu kan secara terbuka. Kegiatan pada setiap fase inilah yang membuat siswa menjadi lebih aktif dalam pembelajaran dengan memulai menyajikan materi, peneliti memberikan pertanyaan yang membingungkan namun siswa tertarik untuk segera mencari jawaban dari permasalahan tersebut untuk mengetahui kemampuan dasar dan siswa mengajukan beberapa pertanyaan untuk pengumpulan data dan hanya bisa dijawab oleh peneliti dengan kata ya atau tidak kemudian peneliti mengarahkan siswa untuk melakukan kelompok terdiri dari 5 orang dan berjumlah 7 kelompok. Kemudian peneliti membagi LKS dan membagikan seperangkat alat percobaan ke masing-masing kelompok sehingga siswa kelihatan sangat antusias melakukan percobaan. Peneliti terlebih dahulu menjelaskan percobaan sebelum siswa melakukan kegiatan tersebut agar siswa lebih paham mengerjakan LKS dan juga mengawasi siswa kemudian siswa mengolah dan menyimpulkan hasil dari percobaan kemudian memperesentasikannya, disinilah siswa dituntut untuk dapat bekerja sama dan memberikan masukan-masukan pada siswa lain sehingga siswa yang kurang mampu menjadi lebih termotivasi untuk mempelajari materi yang kurang dimengerti.

Berdasarkan perolehan data, peningkatan aktivitas siswa persentase skor rata-rata peningkatan aktivitas antara kelas eksperimen dan kelas kontrol sangat berbeda. Pada pertemuan I rata-rata aktivitas siswa kelas eksperimen sebesar 67,61. Pada pertemuan II terjadi peningkatan menjadi 71,23. Pada pertemuan III rata-rata aktivitas siswa semakin meningkat sebesar 73,15, Hal ini karena siswa sudah mampu memahami langkah-langkah yang di instruksikan peneliti dan siswa semakin tertarik oleh kejadian nyata yang mereka lihat dengan adanya praktikum, mereka tidak hanya sekedar mengetahui teori dari buku atau penjelassan dari peneliti akan tetapi mereka dapat membuktikannya langsung secara praktek. Sedangkan pada kelas kontrol dengan menerapkan pembelajaran konvensional, ratarata aktivitas siswa masih di bawah kelas eksperimen, ditunjukkan oleh rata-rata aktivitas pertemuan I sebesar 53,89, pertemuan II sebesar 61,5 , pertemuan III sebesar 67,23. Siswa kelas kontrol yang aktif dalam belajar sangatlah sedikit dan masih banyak siswa yang pasif. Dari hasil observasi diperoleh ratarata aktivitas kelas eksperimen dari pertemuan I sampai pertemuan III sebesar 72,11 (kategori aktif) dan rata-rata aktivitas kelas kontrol dari pertemuan I sampai pertemuan III sebesar 59,45 (kategori cukup aktif). Hal ini dikarenakan kegiatan proses kegiatan pembelajaran dikelas eksperimen lebih bervariasi dari pada dikelas kontrol sehingga lebih menarik dan berkesan bagi siswa untuk belajar. 


\begin{tabular}{lrr}
\multicolumn{1}{c}{$\begin{array}{c}\text { Persentase } \\
\text { skor }\end{array}$} & rata-rata \\
keterampilan & antara & kelas \\
eksperimen dan kelas & kontrol \\
sangat berbeda. & Penilaian \\
keterampilan siswa & pada kelas \\
eksperimen & & mengalami \\
peningkatan & & disetiap
\end{tabular}
pertemuannya. Pada pertemuan I sebesar 69,05, petemuan II sebesar 70,94 dan pada pertemuan III sebesar 70,66. Rata-rata persentase penilaian keterampilan kelas eksperimen dengan menggunakan model pembelajaran inquiry training sebesar 70,94 yang termasuk dalam kategori baik. Hal ini dikerenakan adanya metode eksperimen sehingga dapat mengembangkan ide melalui diskusi dan kerjasama serta menumbuhkan ketertarikan dan minat siswa dalam belajar sehingga diharapkan dapat meningkatkan keterampilan siswa.

Penilaian sikap siswa pada kelas eksperimen juga lebih tinggi dari kelas kontrol. Rata-rata persentase penilaian sikap kelas eksperimen dengan menggunakan model pembelajaran inquiry training sebesar 62,05 yang termasuk dalam kategori baik sedangkan rata-rata persentase penilaian sikap kelas kontrol dengan menggunakan pembelajaran konvensional adalah 57,60 yang termasuk dalam kategori cukup baik.

Berdasarkan penelitian ini penggunaan model pembelajaran inquiry training dapat meningkatkan hasil belajar dan aktivitas siswa, tetapi dalam pembelajaran masih ada kendala yang dihadapi yaitu ketika kerja kelompok berlangsung masih terdapat siswa yang kurang aktif, sehingga kegiatan kelompok selalu didominasi oleh orang yang sama. Terlihat pada siswa dituntut berhipotesis yaitu pada saat pengumpul data verifikasi dan eksperimentasi, ada beberapa siswa yang memilih duduk diam dan menunggu hasil yang diperoleh oleh temannya dari pada ikut berpartisipasi dengan temannya untuk memperoleh data tersebut, hal ini dikarenakan kebiasaan siswa yang belum terbiasa dalam bekerjasama dalam belajar. Model ini akan lebih baik apabila siswa terlibat aktif selama proses belajar melalui kerja kelompok, maka sebaiknya perlu menambahkan beberapa observer agar pembela jaran lebih terarah dan terawasi dalam pengumpulan data. Peneliti juga mengalami kesulitan dalam mengalokasikan waktu pada saat siswa mengajukan hasil diskusinya sehingga tidak semua kelompok dapat menyajikan hasil diskusinya, model ini akan lebih baik apabila peneliti mempertimbangkan pembagian waktu setiap fasenya secara efisien, maka sebaiknya peneliti harus memper hatikan waktu pada tahap "mengolah, merumuskan penje lasan", karena pada tahap ini hampir semua siswa ingin menampilkan hasil diskusinya untuk memberikan masukan-masukan pada siswa dikelompok lain.

Hasil belajar yang diperoleh dalam peneliti ini menggunakan alat ukur berupa tes tertulis dalam bentuk tes esai dan pedoman penskoran aktivitas siswa. Harapan yang terkandung dalam model ini belum semuanya tercapai dengan hasil yang sangat baik, adapun faktor yang menyebabkan kondisi ini terjadi adalah siswa belum 
terbiasa diajarkan dengan menggunakan model pembelajaran inquiry training sehingga butuh penyesuaian dengan siswa saat proses pembelajaran berlangsung. Oleh sebab itu, hendaknya dalam proses pembela jaran sebaiknya siswa diajarkan dengan menggunakan model pembelajaran yang lebih variatif supaya siswa mampu memahami materi pelajaran-pelajaran fisika secara efektif dan efisien.

Berdasarkan hasil penelitian dan pengujian hipotesis dapat dilihat bahwa rata-rata hasil belajar siswa pada kelas eksperimen lebih tinggi daripada rata-rata hasil belajar pada kelas kontrol, berarti hasil belajar fisika dengan menggunakan model inquiry training lebih baik daripada pembelajaran konvensional, sehingga dapat disimpulkan bahwa ada pengaruh penerapan model pembelajaran inquiry training pada materi kalor di kelas VII Semester II SMP Swasta An-Nizam Medan T.P. 2013/2014.

\section{KESIMPULAN DAN SARAN}

Kesimpulan

Peningkatan aktivitas belajar siswa dengan menggunakan model pembelajaran inquiry training mengalami peningkatan, pada pertemuan I sebesar 67,61, pada pertemuan II sebesar 71,23, pada pertemuan III sebesar 73,14, dengan rata-rata nilai keseluruhan sebesar 70,66 dan penigkatan aktivitas belajar siswa dengan menggunakan pembelajaran konvensional pada pertemuan I sebesar 53,89, pada pertemuan II sebesar 61,5, pada pertemuan III sebesar 67,23, dengan rata-rata nilai keseluruhan 60,87.
Berdasarkan hasil analisis perhitungan uji $t$, secara signifikan ada pengaruh penerapan model pembelajaran inquiry training pada materi pokok kalor di kelas VII semester II SMP Swasta An-Nizam Medan T.P 2013/2014.

\section{Saran}

Berdasarkan hasil dan kesimpulan dalam penelitian ini, maka peneliti mempunyai beberapa saran, yaitu: Kepada peneliti selanjutnya, pada saat proses pembelajaran berlangsung sebaiknya menambahkan beberapa observer untuk membantu siswa agar pembelajaran lebih terarah dan mampu mengawasi serta mengamati siswa dalam mengumpulkan data verifikasi dan eksperimentasi. Kepada peneliti selanjutnya, selama proses pembelajaran berlangsung sebaiknya lebih memperhatikan efisiensi waktu di setiap tahap model pembelajaran inquiry training.

\section{DAFTAR PUSTAKA}

Arikunto, S., (2009), Dasar-Dasar Evaluasi Pendidikan (Edisi

Harahap, D. T., (2012), Pengaruh Model Pembelajaran Inquiry Training Terhadap Hasil Belajar Siswa Pada Materi Zat dan Wujudnya Kelas VII Semester 1 di MTS Al Washliyah Tembung T.P 2012/2013., Skripsi, FMIPA Unimed, Medan.

Joyce, B., Weil. M., dan Calhoun, E., (2009), Models of Teaching; Model-Model Pengajaran Edisi Kedelapan, Pustaka Pelajar, Yogyakarta. 
Sudjana., (2005), Metoda Statistika, Tarsito, Bandung.

Sudjana, N., (2009), Penilaian Hasil

Proses Belajar Mengajar, PT.

Remaja Rosdakarya, Bandun 